\title{
Factors controlling the distribution of diatoms and Phaeocystis in the Ross Sea
}

\author{
A. Goffart ${ }^{\mathrm{a}, *}$, G. Catalano ${ }^{\mathrm{b}, 1}$, J.H. Hecq ${ }^{\mathrm{a}, 2}$ \\ a Université de Liège, Unité d'Ecohydrodynamique B5, B 4000 Liège, Sart-Tilman, Belgium \\ ${ }^{\mathrm{b}}$ CNR, Istituto Talassografico, Viale Gessi 2, I 34123 Trieste, Italy
}

Received 15 April 1999; accepted 20 October 1999

\begin{abstract}
The spatial and temporal distributions of phytoplankton pigments were investigated in the western and south central Ross Sea during austral spring 1994 and summer 1990. Large gradients in biomass and phytoplankton community composition were observed both in the east-west and south-north directions, in relation to differences in water column structure and stability, which themselves depend on the processes of ice retreat within the different areas. Important are melting in the western Ross Sea, which induces strong stratification, and ice breakup and wind stress in the south central Ross Sea, which result in deep mixing and weakly stratified waters. In the western Ross Sea, the highest chlorophyll $a$ (chl. $a$ ) concentrations observed in this study $\left(129-358 \mathrm{mg} \mathrm{m}^{-2}\right.$ in the upper $\left.100 \mathrm{~m}\right)$ were tightly coupled to the stratified region of meltwater influence and were dominated by diatoms, as indicated by elevated fucoxanthin concentrations $\left(89-239 \mathrm{mg} \mathrm{m}^{-2}\right.$ in the upper $100 \mathrm{~m}$ ). In the diatom bloom area, high levels of phaeophorbides $a$ (maximum value of $192 \mathrm{mg} \mathrm{m}^{-2}$ in the upper 100 $\mathrm{m}$ ) indicated that the dominant grazers, identified as Limacina helecina and copepods [Hecq, J.H., Magazzù, G., Goffart, A., Catalano, G., Vanucci, S., Guglielmo, L., 1992. Distribution of planktonic components related to vertical structure of water masses in the Ross Sea and the Pacific sector of the Southern Ocean. In: Anonymous, Atti del $9^{\circ}$ congresso A.I.O.L., Santa Margherita Ligure, 20-23 Novembre 1990, 665-678], transferred a sustained part of the diatom production to the herbivore trophic level. Synthesis of our data with published information suggests that the diatom bloom we observed in the western Ross Sea was dominated by the species Fragilariopsis curta, and occurs annually off the coast of Victoria Land from $72^{\circ} 30^{\prime} \mathrm{S}$ to $77^{\circ} \mathrm{S}$ within $100-250 \mathrm{~km}$ from the coastal ice edge. It is assumed to persist on the order of $2.5-3$ months during summer. In the south central Ross Sea, which was characterized by a poorly or unstratified water column, moderate chl. $a$ concentrations $\left(55-186 \mathrm{mg} \mathrm{m}^{-2}\right.$ in the upper $100 \mathrm{~m}$ ) were found in the polynya and in the ice-edge area in early spring. The $19^{\prime}$-hexanoyloxyfucoxanthin $\left(19^{\prime}-\mathrm{HF}\right)$, a biomarker for Phaeocystis, was the major contributor to the total carotenoid abundance (29-132 $\mathrm{mg} \mathrm{m}^{-2}$ in the upper $100 \mathrm{~m}$ ), corroborating the hypothesis that Phaeocystis are well adapted to develop in a relatively mixed water column. At the northern limit of the polynya, a quite narrow (ca. $30 \mathrm{~km})$ diatom bloom (31-67
\end{abstract}

\footnotetext{
* Corresponding author. Fax: +32-4-366-2355.

E-mail addresses: a.goffart@ulg.ac.be (A. Goffart), giulio.catalano@itt.ts.cnr.it (G. Catalano), jh.hecq@ulg.ac.be (J.H. Hecq).

${ }^{1}$ Fax: +39-40-308-9410.

${ }^{2}$ Fax: $+32-4-366-2355$.
} 
mg fucoxanthin $\mathrm{m}^{-2}$ in the upper $100 \mathrm{~m}$ ) overlapped with the Phaeocystis bloom in the slightly stratified marginal ice zone. This was an area of increased grazing pressure by various types of herbivorous zooplankton, among which very large amounts of krill were observed. (C) 2000 Elsevier Science B.V. All rights reserved.

Keywords: Ross Sea; Phaeocystis; diatoms

\section{Introduction}

At the beginning of the austral summer, the usual season of oceanographic cruises in the Southern Ocean, the coastal regions, the ice edges and the frontal zones are often the site of remarkable phytoplankton blooms, both in the ice and in open water. In these areas, massive diatoms blooms are frequently observed (e.g. El-Sayed, 1970; Heywood and Priddle, 1987; Fryxell and Kendrick, 1988; Knox, 1994). These observations support the classical concept of the Antarctic marine food chain (diatomskrill-whales), giving large diatoms a predominant position in the pelagic system (Guillard and Kilham, 1977). However, during the last two decades, it has been recognized that algal taxa belonging to the "less than $10 \mu \mathrm{m}$ " community may predominate under certain conditions (Jacques and Panouse, 1991; Jochem et al., 1995). Attention has been paid to the role of the small diatoms (3-6 $\mu \mathrm{m}$ in length), which often constitute the bulk of the phytoplankton community (Knox, 1994), and to the presence of prymnesiophytes and other flagellates, which may contribute significantly to the total phytoplankton biomass (Gieskes and Elbrächter, 1986; Andreoli et al., 1995; Barlow et al., 1998).

Satellite imagery has revealed that among the greatest accumulations of phytoplankton around the Antarctic continent occur in the Ross Sea, where large coastal polynyas develop during the spring (Comiso et al., 1993; Arrigo and McClain, 1994). Although surface waters in the Ross Sea generally have sufficient nutrients to sustain phytoplankton growth (Nelson and Tréguer, 1992; Tréguer et al., 1994), a high degree of spatial biological variability and substantial gradients in phytoplankton biomass, primary production and nutrients fields are observed between the western and the south central regions (e.g. El-Sayed et al., 1983; Gordon, 1994; DiTullio and Smith, 1996; Catalano et al., 1997).

In the western Ross Sea, maps of pigment concentration determined by analysis of CZCS imagery revealed that an intense phytoplankton bloom developed by mid-December in the Terra Nova Bay polynya (Arrigo and McClain, 1994). Later in the season (January-February), field studies conducted between $72^{\circ} 30^{\prime} \mathrm{S}$ and $77^{\circ} \mathrm{S}$ revealed that extensive diatom blooms are produced by the receding ice edge off the coast of Victoria Land. Such blooms occur annually, and extend 100-250 km out from the dense pack-ice (Smith and Nelson, 1985; Wilson et al., 1986; Nelson and Tréguer, 1992; DiTullio and Smith, 1995; Nelson et al., 1995). The high-biomass core of phytoplankton is confined to a lens of lowsalinity meltwater which coincides spatially with the region of greatest nutrient depletion (Smith and Nelson, 1985; Nelson and Smith, 1986), indicating a long and intense period of production. The dominant species in the bloom is the nanoplanktonic pennate diatom Fragilariopsis curta, which constitutes up to $85 \%$ of the total cell number (Smith and Nelson, 1986).

In the south central Ross Sea, which includes the region where the first open water appears in spring with the formation of the Ross Sea polynya (Arrigo et al., 1998; Hecq et al., 1999), Phaeocystis spp. blooms are observed in the weakly stratified waters. Phaeocystis blooms typically develop from November to February (El-Sayed et al., 1983; Palmisano et al., 1986; Smith and Gordon, 1997) and appear to be localized approximately south of $76^{\circ} \mathrm{S}$, between the Ross Ice Shelf and the $500 \mathrm{~m}$ depth shelf break (Ainley and Jacobs, 1981; El-Sayed et al., 1983). In McMurdo Sound, blooms of Phaeocystis are a regular annual event (Knox, 1990). Smith and Gordon (1997) suggest that the onset of the phytoplankton growth in the southern Ross Sea occurs at the beginning of October, which is substantially earlier than has been observed in the water column anywhere in the coastal Antarctic, and emphasizes the hyperproductive nature of the Ross Sea polynya.

Several related factors have been proposed to explain the variability of phytoplankton development within the Ross Sea, such as meteorological condi- 
tions (Arrigo et al., 1998), sea ice extent, type and thickness (Leventer and Dunbar, 1996), stratification of the water column (Smith and Nelson, 1985), light levels in the photic zone (El-Sayed et al., 1983), and iron concentrations (Martin et al., 1990; Sedwick and DiTullio, 1997). However, the causes and the magnitude of the spatial and temporal variations in phytoplankton communities in the western and south central Ross Sea are not completely understood. Moreover, the fate of the phytoplankton blooms is still largely unknown, although the large zooplankton and marine mammals' populations depend ultimately on primary producers at the base of the food web.

The first objective of this paper is to examine the spatial and temporal distributions of phytoplankton in the western and south central Ross Sea, during the austral spring (November-December) and summer (January), using pigments measured by HPLC as biomarkers. The pigment data are related to nutrient conditions and physical structure of the water column in order to provide insight into the factors controlling the composition of the phytoplankton community. The second objective is to discuss the role that the processes of ice melting, polynya opening, and zooplankton grazing might have on phytoplankton dynamics in the western and south central Ross Sea.

\section{Material and methods}

Field studies took place as part of the Italian National Antarctic Program and were conducted in the Ross Sea during cruises in two separate years (Fig. 1, Table 1). The first set of data was collected during the austral summer (5th Italiantartide Expedi-

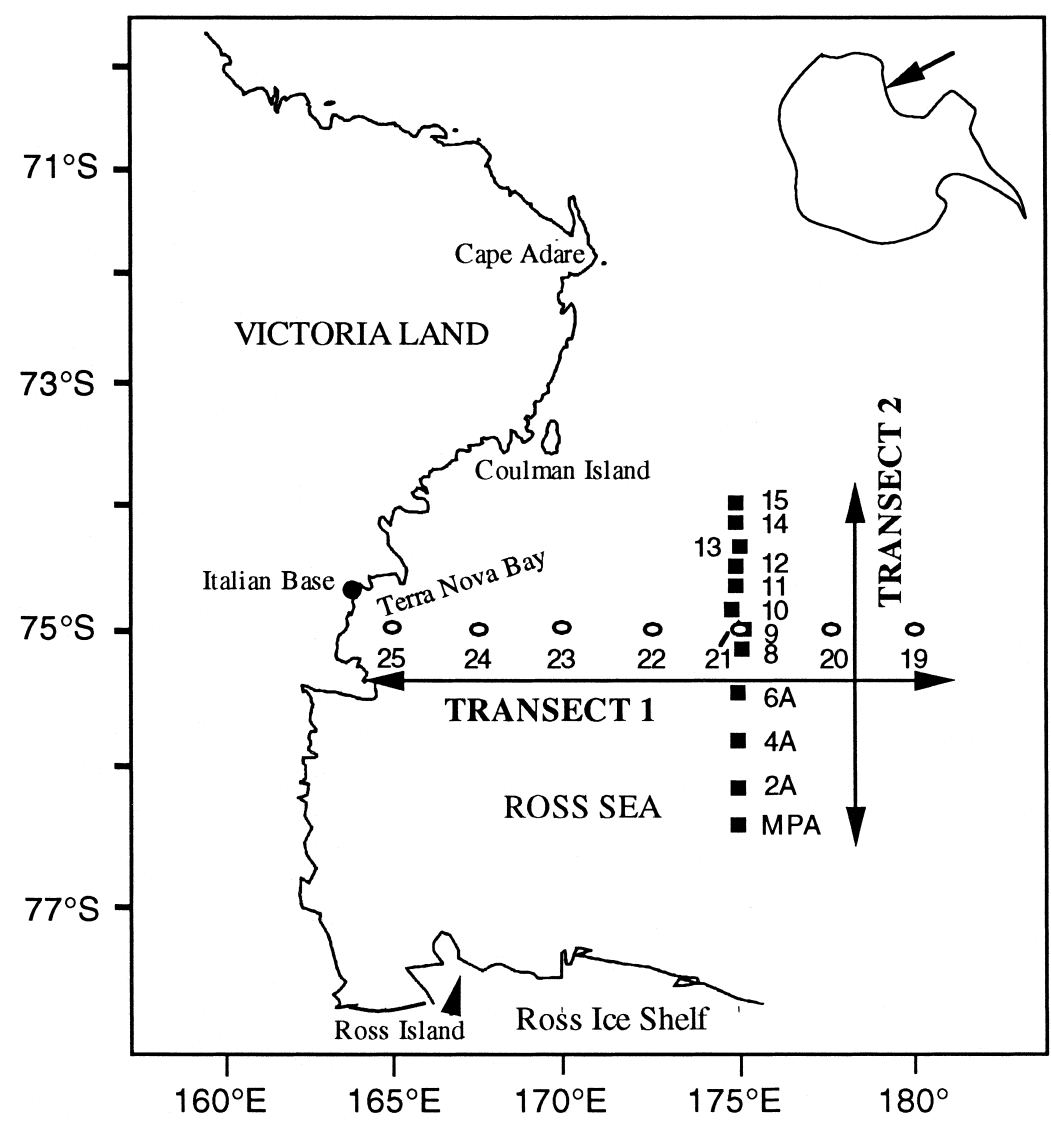

Fig. 1. Map of stations location during this study. 
Table 1

Position and calendar of the transects used in this study

\begin{tabular}{lllll}
\hline Transects & Stations & Latitude & Longitude & Period \\
\hline Transect 1 & $19,20,21,22,23,24,25$ & $75^{\circ} \mathrm{S}$ & $165^{\circ} 02^{\prime} \mathrm{E}-179^{\circ} 56^{\prime} \mathrm{E}$ & $01-06$ January 1990 \\
Transect 2 & $\mathrm{MPA}, 2 \mathrm{~A}, 4 \mathrm{~A}, 6 \mathrm{~A}, 8,9,10,11,12,13,14,15$ & $76^{\circ} 27^{\prime} \mathrm{S}-73^{\circ} 59^{\prime} \mathrm{S}$ & $175^{\circ} \mathrm{E}$ & $20-26$ November 1994 \\
\hline
\end{tabular}

tion), along an east to west transect at $75^{\circ} \mathrm{S}$, from the open water to the Terra Nova Bay polynya (transect 1). On the "Rossmize" cruise, a south-north section across the Ross Sea polynya was sampled in November at $175^{\circ} \mathrm{E}$, following the northward ice retreat (transect 2). The Rossmize cruise represents one of the earliest entries into the Ross Sea polynya during the austral spring by an oceanographic vessel.

Along transect 1, vertical sampling was carried out on hydrographic stations by means of twelve 10-1 Niskin bottles attached to a CTD rosette. Samples from transect 2 were collected with a SBE 32 Carousel sampler, equipped with twenty-four 12-1 Niskin bottles. In the upper $200 \mathrm{~m}$, standard sampling depths were the surface, 10, 25, 50, 100 and $200 \mathrm{~m}$. Moreover, 2-5 variable depths were added to the hydrological casts according to the stratification and the attenuation of incident PAR.

Continuous depth profiles of temperature and salinity were collected at each station. Density values were computed from these data and are reported in Artegiani et al. (1992) and Russo et al. (1997). Because water-column stability is an important controlling factor for the biomass and structure of phytoplankton communities, $E_{\max }\left(\mathrm{m}^{-1} \times 1000\right)$, the stability index of the depth corresponding to the maximum density gradient, was calculated according Mitchell and Holm-Hansen (1991) and Catalano et al. (1997).

During the 5th Italiantartide Expedition, nitrate and silicate concentrations were determined on board by means of a Technicon II Autoanalyser (Hansen and Grasshoff, 1983) while during the Rossmize cruise, an Alpkem autoanalyser was adopted according to ALPKEM (1992a,b).

Samples of 11 for pigment determination were filtered at low vacuum pressure through Whatman $\mathrm{GF} / \mathrm{F}$ filters. They were immediately frozen at $-25^{\circ} \mathrm{C}$ until analysis on board, some hours later. Frozen filters were extracted in $100 \%$ methanol us- ing grinding and refiltration to remove cellular debris. Phytoplankton pigments and their degradation products were separated and quantified by high performance liquid chromatography (HPLC), following the procedures of Mantoura and Llewellyn (1983) and Williams and Claustre (1991), for the 5th Italiantartide and Rossmize cruises, respectively. Chlorophyll $a$ (chl. $a$ ) is used as the universal index of phytoplankton biomass. Fucoxanthin and 19'hexanoyloxyfucoxanthin $\left(19^{\prime}-\mathrm{HF}\right)$ are used as chemotaxonomic tools to identify diatoms (Jeffrey, 1980; Claustre et al., 1994; Barlow et al., 1998) and prymnesiophytes, respectively (Gieskes and Kraay, 1986; DiTullio and Smith, 1995; Jeffrey et al., 1997). Prymnesiophytes are very common in the Ross Sea and consist mainly of Phaeocystis antarctica (Innamorati et al., 1990; Marino and Cabrini, 1997). Among the phaeopigments, phaeophorbides $a$ are here considered. They are produced from the breakdown of chl. $a$ by the enzymatic activity of the zooplankton digestive system, and are utilized here as a quasi-conservative tag for the detection of ingestion of phytoplankton by feeding herbivores (Jeffrey, 1974; Welschmeyer and Lorenzen, 1985; Vernet and Lorenzen, 1987; Jeffrey et al., 1997).

\section{Results}

\subsection{Western Ross Sea: transect 1}

On the first cruise, transect 1 was situated in a region of open water with drifting ice floes. The pack-ice edge was located between the coast of Victoria Land and the westernmost station (station 25). The major feature of the hydrographic field was a well-established lens of low-density low-salinity surface water from station 22 to station 25 (Fig. 2). Within this stable surface layer, almost certainly produced by ice melt, a very strong thermohaline 

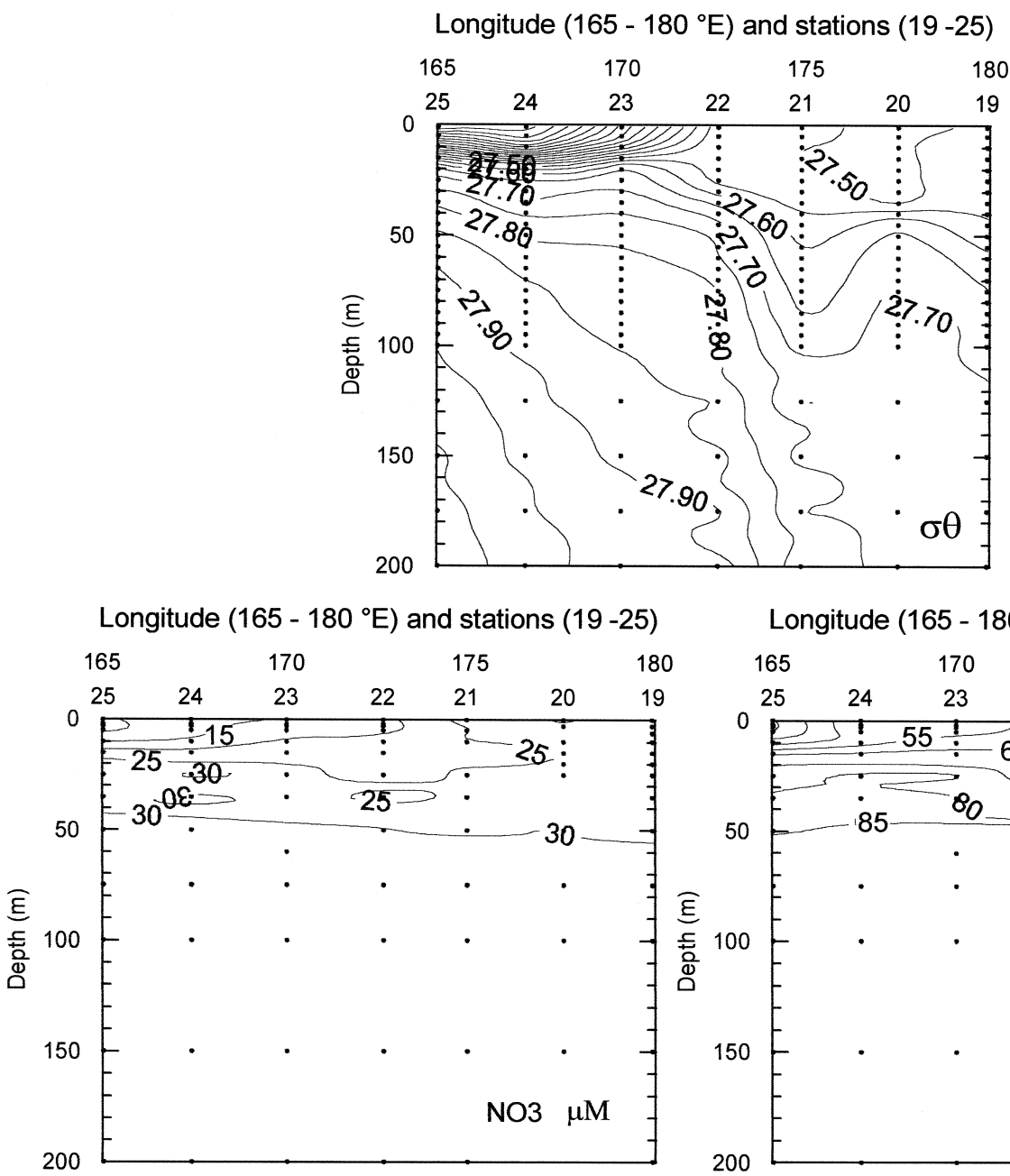

Longitude $\left(165-180^{\circ} \mathrm{E}\right)$ and stations $(19-25)$

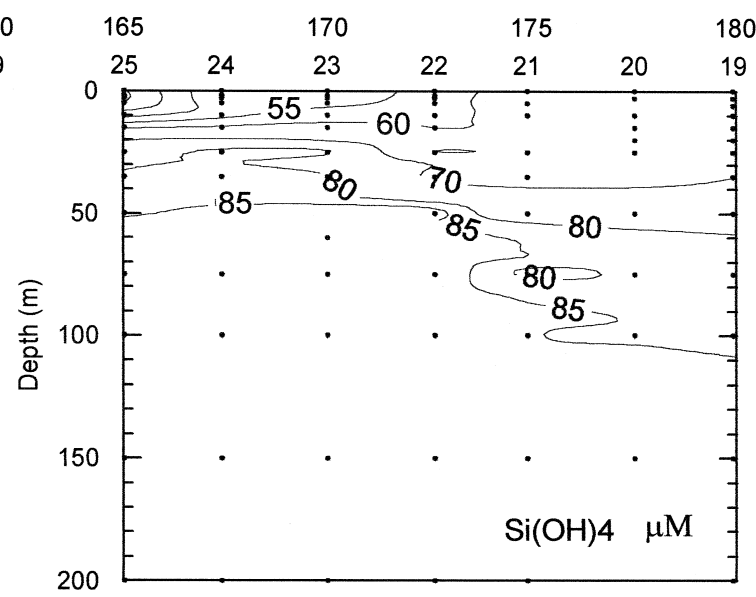

Fig. 2. Distribution of $\sigma_{\theta}$, nitrate $(\mu \mathrm{M})$ and silicate $(\mu \mathrm{M})$ in the upper $200 \mathrm{~m}$ along transect 1. $\sigma_{\theta}$ data from Artegiani et al. (1992).

gradient was observed, with temperature and salinity varying from values $>1{ }^{\circ} \mathrm{C}$ and $<33.4$ at the surface to values $<-1.6^{\circ} \mathrm{C}$ and $>34.5$ at $30 \mathrm{~m}$ (data from Artegiani et al., 1992). As a whole, a stable upper mixed layer prevailed for the westernmost stations (stations 22-25), with $E_{\max }$ varying from 21 to $107 \mathrm{~m}^{-1} \times 1000$. Lower values of $E_{\max }$ in eastern part of the section $\left(7-22 \mathrm{~m}^{-1} \times 1000\right)$ indicated a less stable water column.

Fig. 3 shows the spatial variation of chl. $a$, fucoxanthin, 19'-HF and phaeophorbides $a$ along transect 1. Horizontal distribution of values integrated through the upper $100 \mathrm{~m}$ is also presented. As regards inte- grated chl. a concentrations, a west-east gradient was observed, with a core of biomass over $125 \mathrm{mg}$ chl. $a \mathrm{~m}^{-2}$ in the upper $100 \mathrm{~m}$ extending seaward for approximately $220 \mathrm{~km}$ (stations 25-22). Maximum integrated chl. $a$ reached $358 \mathrm{mg}$ chl. $a \mathrm{~m}^{-2}$ at station 22 and was then followed by a drastic decrease of concentrations proceeding eastward. An area of moderate chl. $a$ concentrations was situated at the eastern end of the transect, around station 20.

Fucoxanthin was the most abundant carotenoid on this transect, and its distribution was similar to that of chl. $a$ (Fig. 3). Diatom biomass, as estimated from fucoxanthin concentrations, was greatest in the upper 


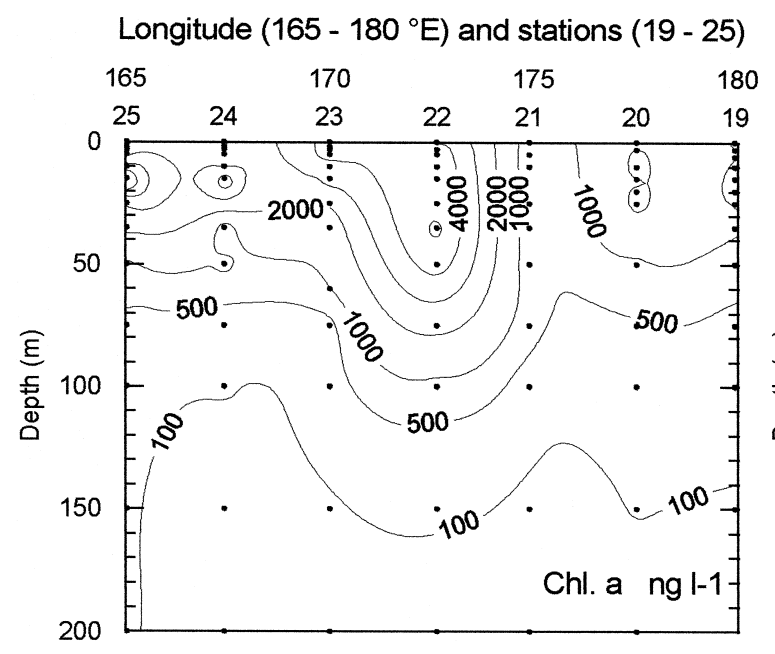

\section{Longitude $\left(165-180^{\circ} \mathrm{E}\right)$ and stations $(19$ - 25)}
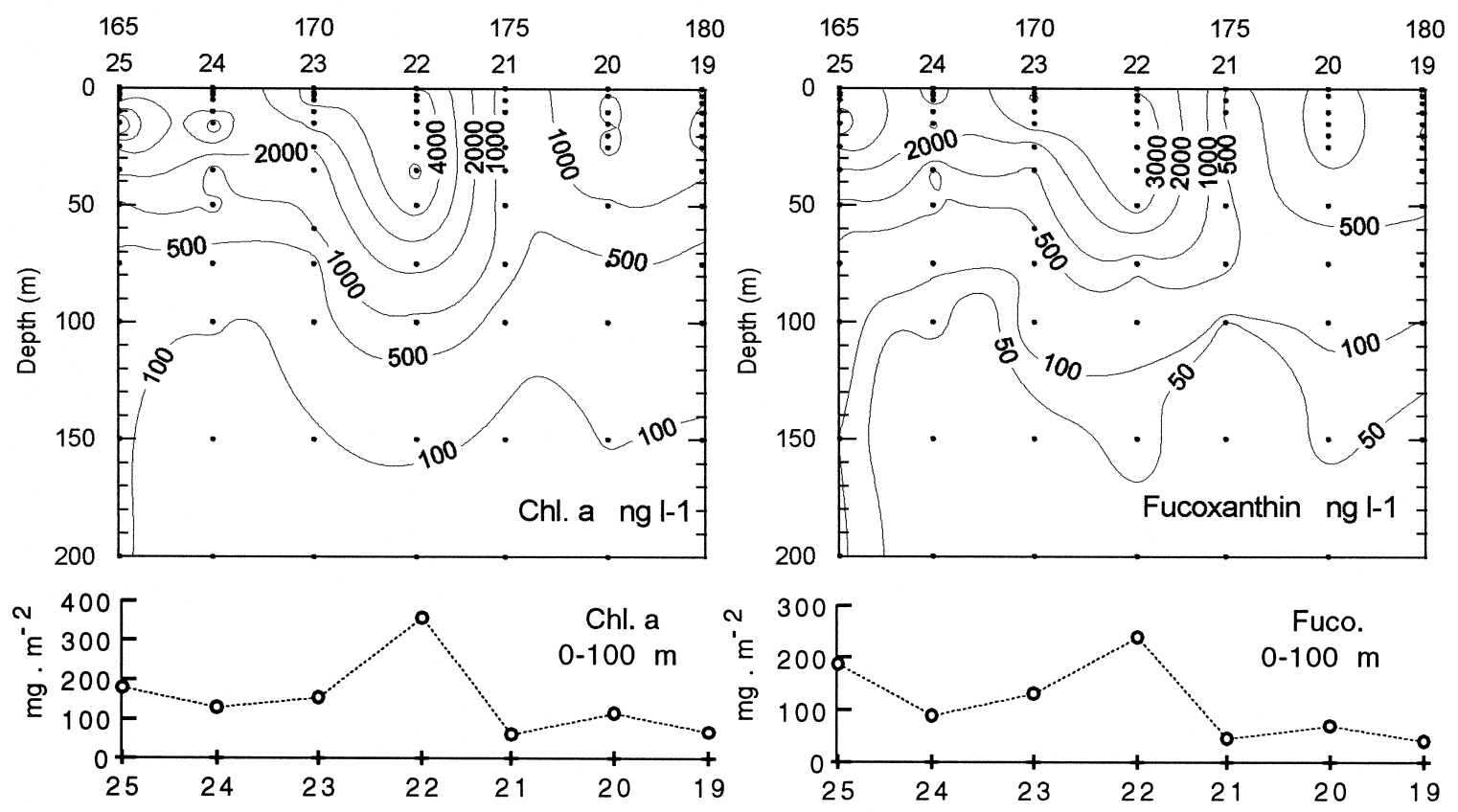

Longitude $\left(165-180^{\circ} \mathrm{E}\right)$ and stations (19 - 25)

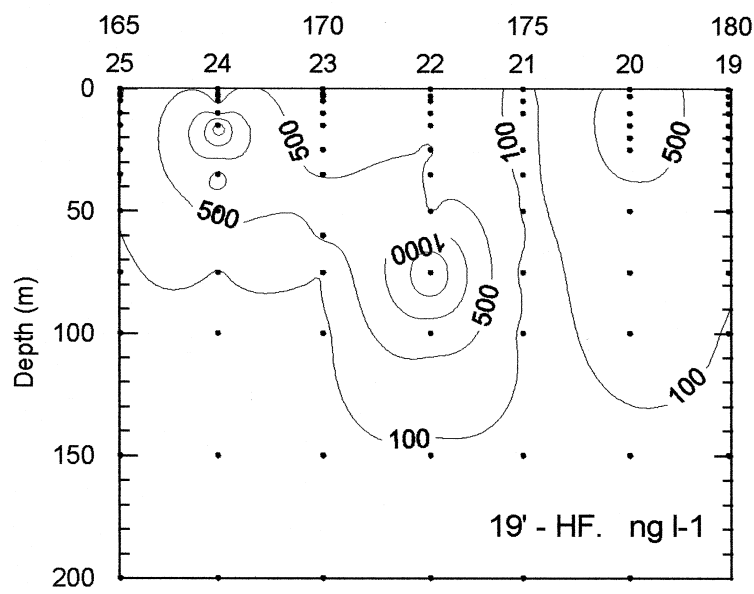

Longitude $\left(165-180^{\circ} \mathrm{E}\right)$ and stations $(19-25)$
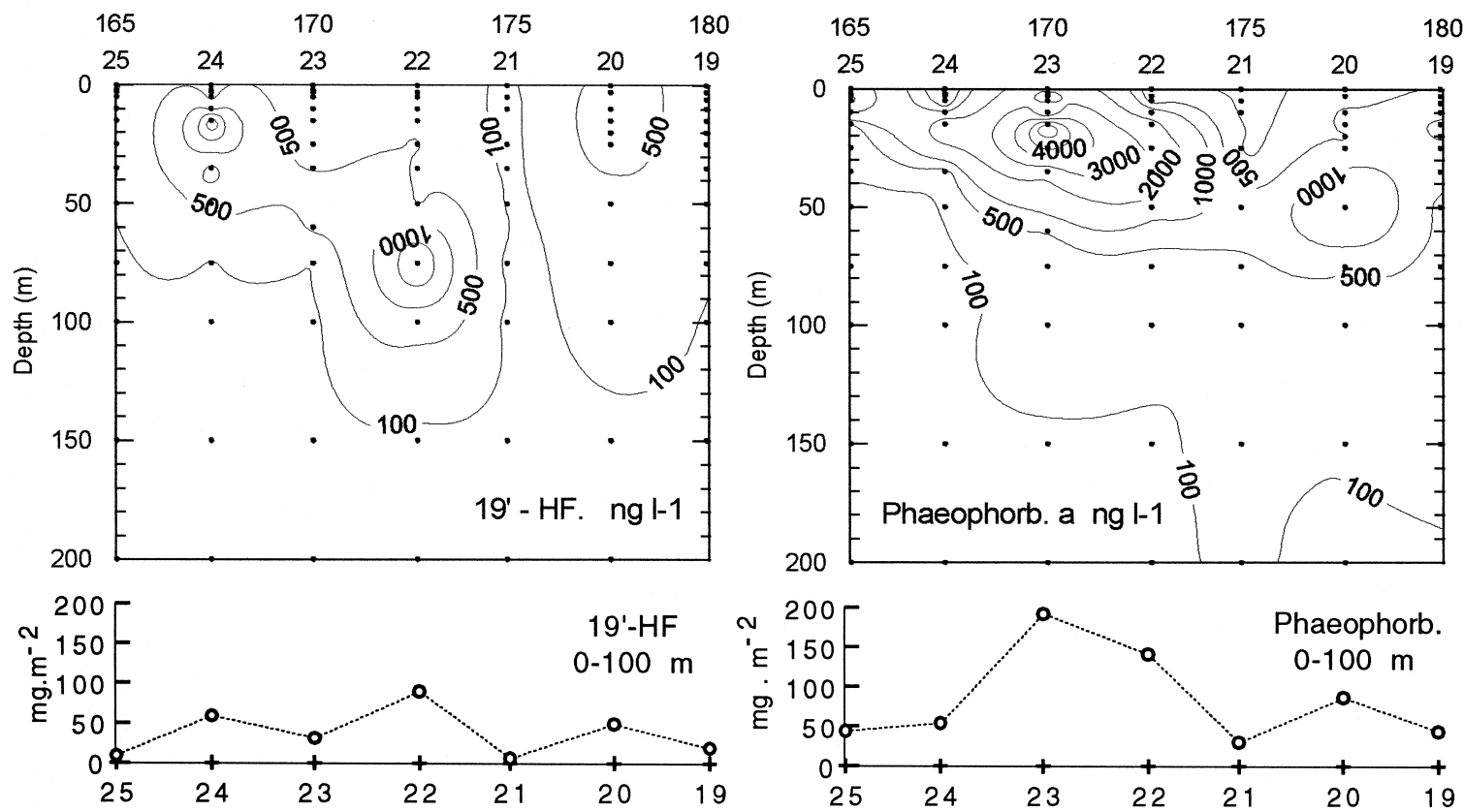

Fig. 3. Distribution of chl. $a$, fucoxanthin, $19^{\prime}$-HF and phaeophorbides $a$ in the upper $200 \mathrm{~m}$ along transect 1 (ng $1^{-1}$ ). Integrated biomasses $\left(0-100 \mathrm{~m}, \mathrm{mg} \mathrm{m}^{-2}\right)$ are shown below each section.

$50 \mathrm{~m}$ of the western portion of the transect and decreased markedly east of station 22 . In the western part of the section, integrated fucoxanthin concentrations in the upper $100 \mathrm{~m}$ ranged from 89 to $239 \mathrm{mg}$ 
$\mathrm{m}^{-2}$, and reached a maximum value at station 22 , where chl. $a$ concentration was maximum.

Integrated 19'-HF, the second most dominant chromophytic pigment, did not show any clear trend of variation moving along the transect. However, the vertical distribution of $19^{\prime}$-HF exhibited a contrast between the western and the eastern parts of the section. In the western part, maxima of $19^{\prime}$-HF concentrations were generally observed below those of fucoxanthin whereas maxima of $19^{\prime}$-HF and fucoxanthin concentrations coincided in the area of moderate chl. a concentrations around station 20 (Fig. 3). Moreover, while fucoxanthin concentration de- creased rapidly with depth, the vertical gradient in $19^{\prime}$-HF concentration was less pronounced.

High levels of phaeophorbides $a$ were found at the stations where chl. $a$ concentrations were elevated (Fig. 3). In the western part of the section, the vertical distribution of phaeophorbides $a$ followed the patterns of chl. $a$ and fucoxanthin. The maximum integrated concentration of phaeophorbides $a$ was seen in the central part of the diatom bloom, and reached the exceptionally high level of $192 \mathrm{mg} \mathrm{m}^{-2}$ in the upper $100 \mathrm{~m}$ at station 23.

The high-biomass region of the bloom was an area of pronounced silicate and nitrate depletions
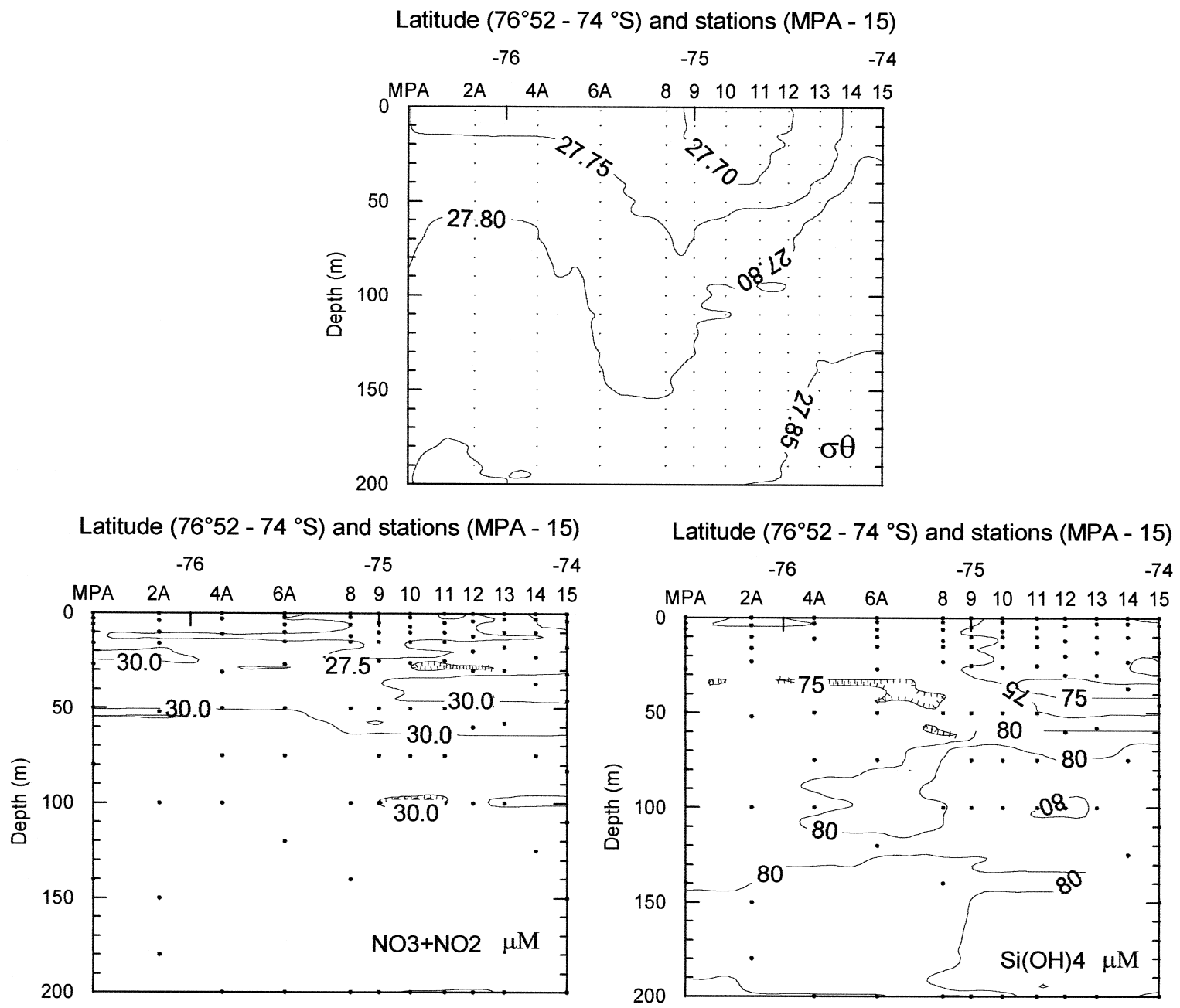

Fig. 4. Distribution of $\sigma_{\theta}$, nitrate + nitrite $(\mu \mathrm{M})$ and silicate $(\mu \mathrm{M})$ in the upper $200 \mathrm{~m}$ along transect 2. $\sigma_{\theta}$ data from Russo et al. (1997). 
(Fig. 2) with their concentrations reduced by up to $30 \%$ of the winter values (deduced from the values
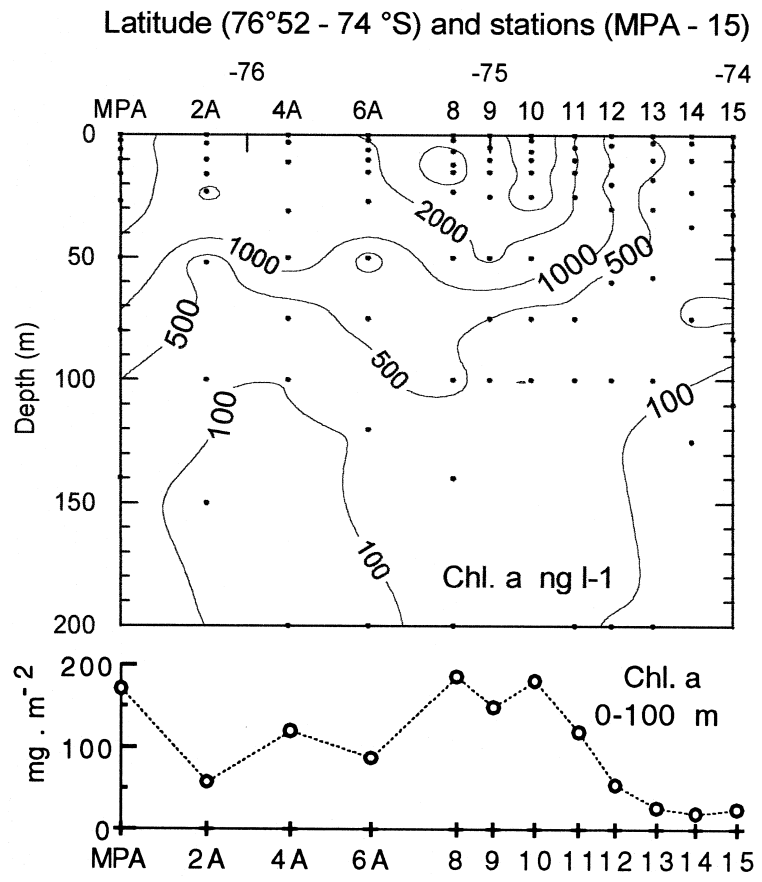

Latitude $\left(76^{\circ} 52-74^{\circ} \mathrm{S}\right)$ and stations (MPA - 15)
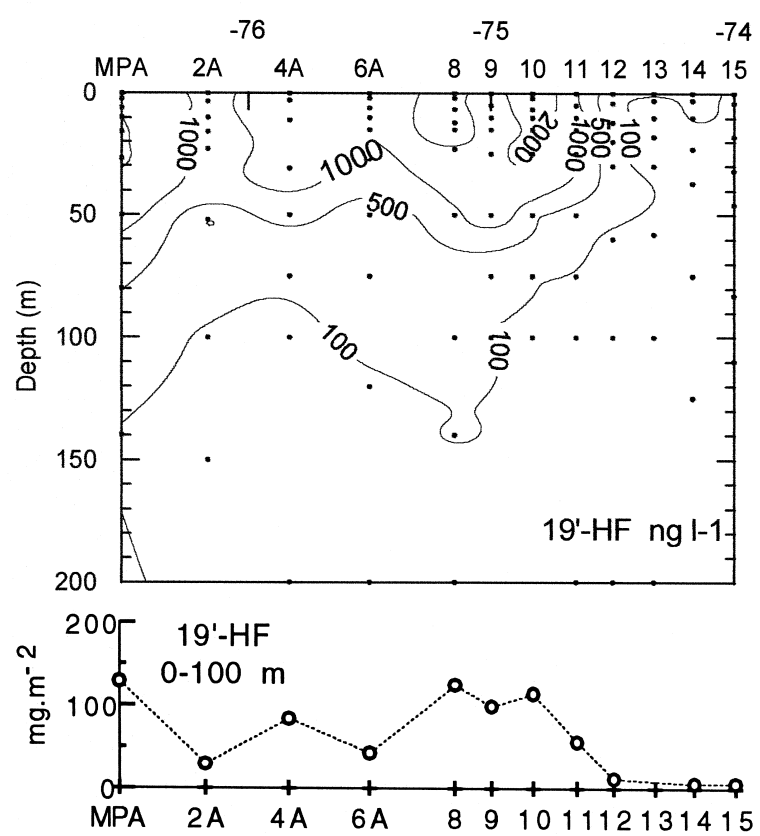

taken immediately below the pycnocline). The most intense nutrient removal occurred for silicate, which

Latitude $\left(76^{\circ} 52-74^{\circ} \mathrm{S}\right)$ and stations (MPA - 15)
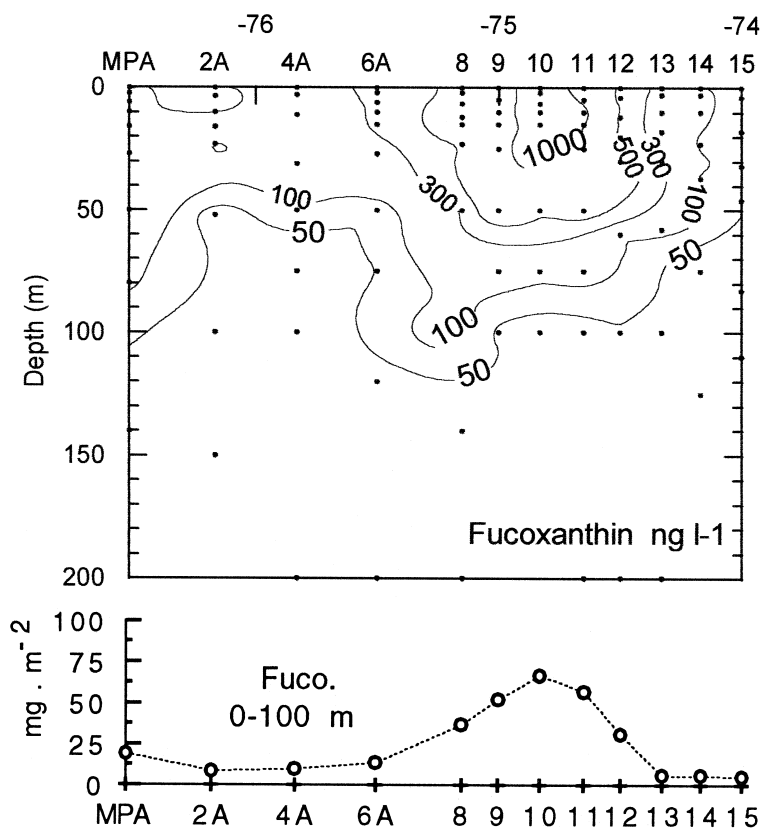

Latitude $\left(76^{\circ} 52-74^{\circ} \mathrm{S}\right)$ and stations (MPA - 15)
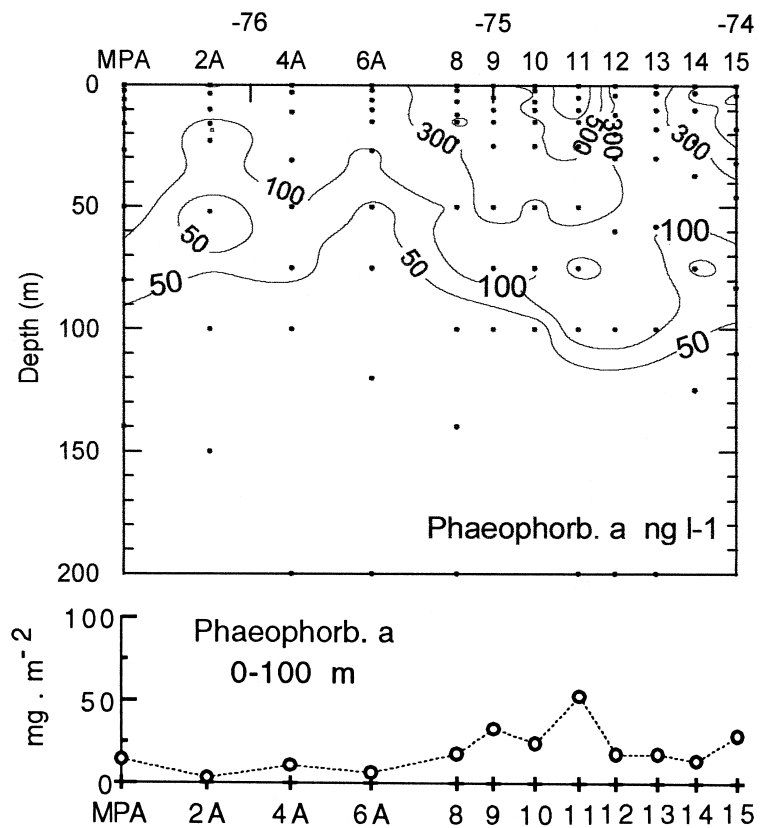

Fig. 5. Distribution of chl. $a$, fucoxanthin, $19^{\prime}-\mathrm{HF}$ and phaeophorbides $a$ in the upper $200 \mathrm{~m}$ along transect 2 (ng $1^{-1}$ ). Integrated biomasses $\left(0-100 \mathrm{~m}, \mathrm{mg} \mathrm{m}^{-2}\right)$ are shown below each section. 
was reduced by about $65 \mu \mathrm{M}$ within the surface mixed layer at station $25(85 \mu \mathrm{M}$ at $50 \mathrm{~m}, 17 \mu \mathrm{M}$ at $5 \mathrm{~m})$. At the same station, nitrate was reduced from ca. $30 \mu \mathrm{M}$ below the pycnocline to $<10 \mu \mathrm{M}$ at the surface.

\subsection{South central Ross Sea: transect 2}

Along transect 2, the area of investigation can be separated into three main regions based on the different ice conditions encountered: the polynya area (stations MPA-8), the marginal ice zone (stations 9-12) and the pack-ice zone (stations 13-15). This pattern was also reflected in the physical, chemical and biological variables focused on in this paper.

In the polynya area, the water column was mostly unstratified (Fig. 4), and its structure reflected a strong vertical mixing, as emphasized by the very low value of the average $E_{\max }\left(6 \mathrm{~m}^{-1} \times 1000\right)$. Within the marginal ice zone, stratification increased slightly (average $E_{\max }$ of $8.5 \mathrm{~m}^{-1} \times 1000$ ), as a result of a small decrease in surface salinity (less than $0.1 \%$ reduction in salinity, data from Russo et al., 1997). Further north, below the pack-ice, the water column reflected a typical homogeneous winter structure.

Similar and moderate standing crops of phytoplankton were found in the polynya and in the ice-edge area (Fig. 5). The polynya had integrated values of chl. $a$ ranging from 58 to $186 \mathrm{mg}$ chl. $a$ $\mathrm{m}^{-2}$ in the upper $100 \mathrm{~m}$ while the ice-edge area showed integrated chl. $a$ from 55 to $181 \mathrm{mg}$ chl. $a$ $\mathrm{m}^{-2}$. Significantly lower levels of chl. $a(20-27 \mathrm{mg}$ chl. $a \mathrm{~m}^{-2}$ ) characterized the pack-ice area.

Along transect 2, 19'-HF was the major contributor to total carotenoid abundance and showed concentrations higher than those of fucoxanthin. The distribution of $19^{\prime}$-HF exactly followed that of chl. $a$, indicating that prymnesiophytes, and Phaeocystis in particular, were present both throughout the polynya

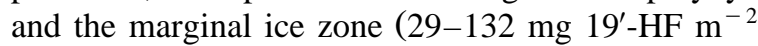
in the upper $100 \mathrm{~m}$ ). The variation of $19^{\prime}$-HF across the polynya and the marginal ice zone did not show any particular tendency. However, 19'-HF exhibits a drastic decrease in the water under the ice, even though it was dominant in melting-ice region.

On the other hand, fucoxanthin, the pigment second in abundance after $19^{\prime}$-HF, was strictly coupled to the marginal ice zone where it showed marked increases $\left(31-67 \mathrm{mg} \mathrm{m}^{-2}\right.$ in the upper $100 \mathrm{~m}$ ) as compared to polynya and pack-ice stations (Fig. 5). The maxima of phaeophorbides $a$, used as grazing tracer, also occurred in the marginal ice zone, where diatoms were most abundant. In that area, an important fraction of phytoplankton production appears to be transferred to higher trophic levels through herbivores, in particular through krill that were present in extremely high concentrations $\left(\approx 29\right.$ tons $\mathrm{km}^{-2}$ at station 11; Azzali, personal communication).

During early spring, nitrate + nitrite and silicate concentrations in the south central Ross Sea were very high (Fig. 4). Ambient concentrations in the $100 \mathrm{~m}$ upper layer ranged from 24.7 to $32.0 \mu \mathrm{M}$ for nitrate + nitrite and from 71.0 to $84.9 \mu \mathrm{M}$ for silicate. The overall nutrient spatial variation was small, with slightly lower concentrations at the ice edge and on the northern side of the transect, below the packice, implying the bloom had not existed very long.

\section{Discussion}

The range in pigment concentrations we report for transects 1 and 2 confirms the presence of substantial gradients in phytoplankton biomass and species distribution within the western and south central Ross Sea. The distributions of phytoplankton seem to be largely controlled by hydrological structure and water column stratification, which are themselves dependent on the mechanisms that govern the concentration of sea ice within the Ross Sea.

In the western Ross Sea, east of Victoria Land and Terra Nova Bay, the stratification of the water column results primarily from the input of low-salinity meltwater, most likely derived from sea ice which melts near the coast and from coastal glaciers (transect 1). The highest phytoplankton concentrations observed in this study were tightly coupled to the region of meltwater influence and were dominated by diatoms, as indicated by the elevated fucoxanthin concentrations. Typically, Fragilariopsis curta is the most abundant species in the sediment record of the western Ross Sea over the past 18000 years (Kellogg and Truesdale, 1979) and dominates the diatom assemblage of other ice-edge blooms reported for the western Ross Sea (e.g. Wilson et al., 1986; DiTullio 
and Smith, 1995). Consequently, its dominance within the ice-edge bloom we studied is assumed.

The overall spatial extent and biomass levels of the bloom we observed were similar to previous reported field observations dealing with summer conditions in the western Ross Sea. Our data suggest the annual occurrence of an intense diatom bloom associated with the coastal ice-edge region and allow us to accurately describe its spatial and temporal characteristics. Synthesis of available information (Table 2) suggests that a diatom-dominated ice-edge bloom extends off the coast of Victoria Land from $72^{\circ} 30^{\prime} \mathrm{S}$ to $77^{\circ} \mathrm{S}$, within $100-250 \mathrm{~km}$ from the coastal ice edge and persists at least from early January to late February. However, pronounced nitrate and silicate depletion observed by early January within the high biomass core of our transect suggests that bloom initiation takes place much earlier in the season. This assumption is confirmed by satellite images, which reveal that substantial chl. $a$ concentrations exist by mid-December in Terra Nova Bay (Arrigo and McClain, 1994). Although it is difficult to assign a time frame for a process controlled by physical conditions, it seems reasonable to infer that the diatom ice-edge bloom of the western Ross Sea persists on the order of 2.5-3 months. Although this estimate involves a number of uncertainties, it allows an appreciation of the temporal pattern of the bloom based on field observations and emphasizes its potential major role in the functioning of the pelagic ecosystem of the Ross Sea.

The only other carotenoid pigment detected in significant concentration within the area of meltwater influence was $19^{\prime}-\mathrm{HF}$, used as marker for prymnesiophytes. The presence of $19^{\prime}$-HF could be attributable to Phaeocystis, whose presence in relatively small numbers $\left(60-17010^{3}\right.$ cells $\left.1^{-1}\right)$ was reported for Terra Nova Bay in January 1990 (Andreoli et al., 1993). The shift between the vertical distributions of fucoxanthin and 19'-HF suggests that $19^{\prime}$-HF containing cells have superior photoadaptative properties, as emphasized by Palmisano et al. (1986), and are able to survive at very low irradiances. For instance, at station 22, maximum of $19^{\prime}-\mathrm{HF}$ concentration was situated below the depth of $0.1 \%$ of light penetration.

Outside of the diatom-dominated ice-edge bloom, chl. $a$ concentrations were markedly lower until approximately $400 \mathrm{~km}$ seaward of the coast, where a secondary, less intense, chl. a maximum was detected in the open water. The open water chl. $a$ maximum was different in its pigment composition from the diatom-dominated ice-edge bloom. It contained fucoxanthin and $19^{\prime}$-HF in similar proportions, indicating a mixed community of diatoms and prymnesiophytes. These observations coincide with those reported for the south eastern Ross Sea $\left(76^{\circ} 30^{\prime} \mathrm{S}\right.$, $\left.175-180^{\circ} \mathrm{E}\right)$ where a secondary chl. $a$ maximum was found in late January 1990, 2-4 weeks after our transect (Nelson et al., 1991). The species composition within this area of moderate phytoplankton biomass was a mixed assemblage of Phaeocystis and numerous diatom species, with Corethron cryophilum and a Chaetoceros species the major contributors to the diatom biomass (Leventer unpublished data in Nelson and Tréguer, 1992).

The distribution of phaeophorbides $a$, in relation to chl. $a$, indicated that zooplankton grazing and phytoplankton biomass were tightly coupled. Within the diatom-dominated ice-edge bloom, grazing pressure significantly reduced the diatom biomass and transferred a sustained part of algal material to the herbivore trophic level. The most abundant mesozooplanktonic grazers were the thecosome pteropods Limacina helecina and copepods (Hecq et al., 1992). Adult and juvenile euphausiids were also observed. Grazing of phytoplankton was maximum in the central part of the bloom, while stations situated closer to the ice-edge were characterized by less grazed and probably younger diatoms based on pigment distributions. Thus, it appears that the stabilization of the upper layer of the water column associated with the receding ice-edge of the western Ross Sea favors diatom growth and accumulation. This is exploited by a classical food web where large herbivorous zooplankton provide the major link to larger animals and play an important role in regulating algal biomass. Moreover, the long duration of this phenomenon must influence substantially the fluxes of biogenic carbon and silica towards apex predators and deep waters.

The physical environment and the water column structure observed in the south central Ross Sea differ markedly from those observed in the western Ross Sea. Physical data along transect 2 demonstrate that very little meltwater had been introduced into 


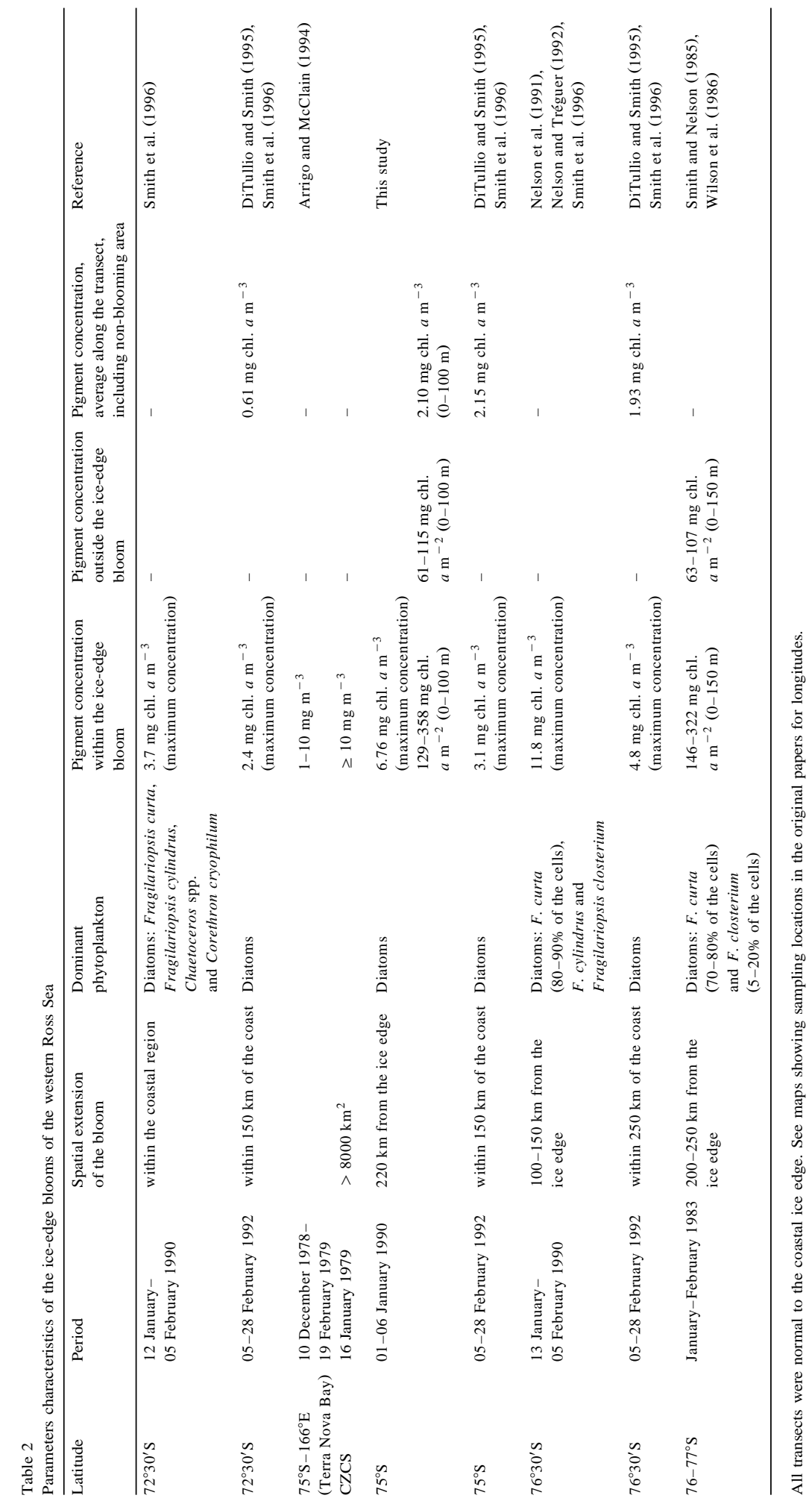


the surface layer, even in the marginal ice zone, as referred to also by Smith and Gordon (1997). These observations suggest that direct melting plays only a minor role in the formation and opening of the Ross Sea polynya north of the Ross Ice Shelf. This hypothesis seems supported by the findings of Arrigo et al. (1998) who demonstrate that the mechanisms of the Ross Sea polynya formation are controlled mainly by air temperature in winter, which determine sea ice thickness and integrity. Polynya formation begins only when the temperature rises and the sea ice increases in brine volume, allowing sea ice breakup. Once ice breakup has begun, a set of complex processes interact to govern the concentration within the Ross Sea polynya, including the influence of surface currents and wind stress on sea ice distribution (Arrigo et al., 1998). With the opening of the polynya, the ice-free area is propagating from the south to the north until the beginning of January when the polynya becomes contiguous with the rest of the Ross Sea (Arrigo and McClain, 1994; Hecq et al., 1999).

As a consequence of these mechanisms of ice retreat, the water-column structure of the south central Ross Sea polynya is characterized by a relatively deep mixed layer, a low stability index, and a quite homogenous nutrient distribution. These conditions favor the presence of a bloom dominated by Phaeocystis, both in the polynya area and often in the weakly stratified marginal ice zone. Phaeocystis dominate in the south central Ross Sea probably because of their ability to maintain near-maximal photosynthetic rates at much lower irradiance levels than can diatoms (Leventer and Dunbar, 1996; Arrigo et al., 1999). By mid to late November, the latitudinal extension of the Phaeocystis bloom covered at least the area of the south central Ross Sea between $76^{\circ} 30^{\prime} \mathrm{S}$ and $74^{\circ} 50^{\prime} \mathrm{S}$ (transect 2). Complementary informations are provided by Smith and Gordon (1997) who observed Phaeocystis dominance at the same period of the same year along a longitudinal transect perpendicular to the Victoria Land coast at $76^{\circ} 30^{\prime} \mathrm{S}$. In both cruises, nutrients and chl. $a$ concentrations exhibited similar distributions. These results clearly indicate that Phaeocystis blooms in early spring in the Ross Sea polynya, when it can outcompete other species in the unstratified or poorly stratified water column.
At the northern limit of the polynya, fucoxanthin concentrations were significantly higher in close proximity to the retreating ice edge than for the open water region where ice had disappeared for some time. A diatom bloom was confined to the slightly stratified area of the marginal ice zone and overlapped with the Phaeocystis bloom. However, the spatial extension the diatom-rich band of the south central Ross Sea was quite narrow (ca. $30 \mathrm{~km}$ ), corresponding with the reduced width of the slightly stratified marginal ice zone. Furthermore, fucoxanthin concentrations in the marginal ice zone of the polynya were approximately three times lower than within the diatom bloom observed in the western Ross Sea.

In spite of its reduced geographical extent, the marginal ice zone of the south central Ross Sea was an area of increased transformation of chl. $a$, mainly through grazing activity as suggested by the greater phaeophorbide levels. The degradation of the algal material appeared to be due to grazing pressure by various types of herbivorous zooplankton, among them the very large amounts of krill. These krill contributed to a total disappearance of the biomass of bloom-forming phytoplankton within 2 weeks (Hecq et al., 1999). Moreover, the diatom-krill assemblage characterizing the marginal ice zone of the polynya (Hecq et al., 1999) attracted remarkable populations of birds and Minke whales in a period of early production when diatoms are scarce in other areas.

To examine the relationship between water column stratification (itself depending on the mechanism of ice retreat) and diatom or Phaeocystis dominance, we plotted $E_{\max }$ against integrated fucoxanthin and 19'-HF for each station of transects 1 and 2 (Fig. 6). The depth of integration $Z(L)$ was calculated according to Catalano et al. (1997), assumed to be the depth of the base of the pycnocline. The maximum observed values of integrated $19^{\prime}$-HF were observed in stations with very low $E_{\max }\left(<10 \mathrm{~m}^{-1}\right.$ $\times 1000)$ corroborating the hypothesis that Phaeocystis are well adapted to a mixed water column (Fig. 6A). These values correspond to the polynya and marginal ice-zone stations of transect 2. However, a low $E_{\max }$ does not necessarily imply a Phaeocystis bloom, as shown for the pack-ice stations of transect 2. In this case, very low irradiance below the pack 


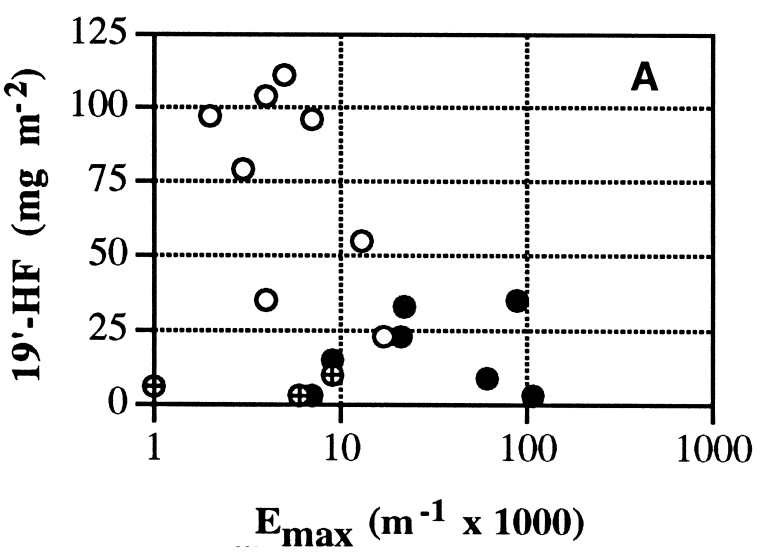

Transect 1

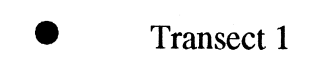

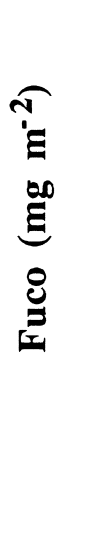

200

\section{- Transect 2 \\ MIZ and polynya}

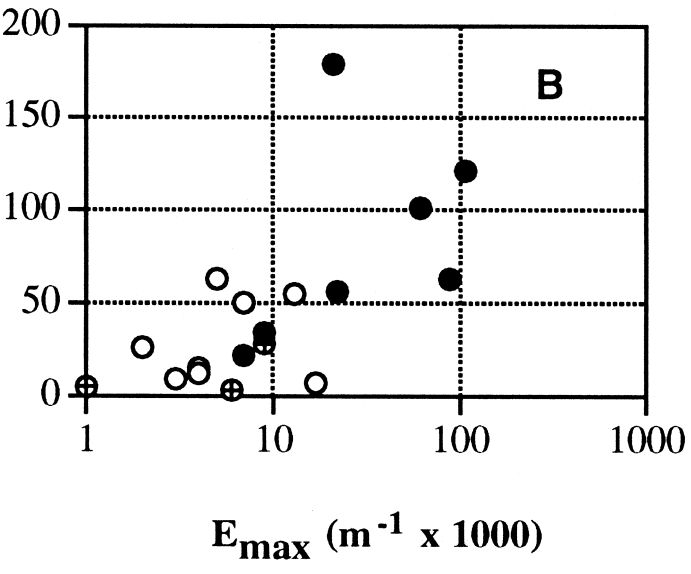

Fig. 6. Maximum vertical stability $E_{\max }\left(\mathrm{m}^{-1} \times 1000\right)$ vs. integrated $19^{\prime}-\mathrm{HF}\left(6 \mathrm{~A}, \mathrm{mg} \mathrm{m}^{-2}\right)$ and fucoxanthin $\left(6 \mathrm{~B}, \mathrm{mg} \mathrm{m}^{-2}\right)$ for transects 1 and 2. Depth of integration $Z(L)$ was calculated according to Catalano et al. (1997).

presumably prevents Phaeocystis growth. On the other hand, diatom abundance showed a positive correlation with water column stability (Fig. 6B). Increasing water stability apparently favored the growth and accumulation of diatom standing crops and allowed them to adapt to a particular light regime.

Recently, evidence of seasonal iron limitation in the Ross Sea provided complementary information on the factors controlling biomass and species distribution in Antarctic shelf waters. Sedwick et al. (2000) showed that diatoms bloom only in the ice-edge regions, where both light and iron, supplied from melting sea ice, are abundant. In the unstratifed waters, Phaeocystis dominated the algal community during spring and early summer in iron-replete conditions ( $>1 \mathrm{nM}$ dissolved $\mathrm{Fe}$ ), as a result of iron supply from upwelled bottom waters. Later in the season, very low iron concentrations in the ice-free waters $(<0.2 \mathrm{nM}$ dissolved $\mathrm{Fe})$ limit both Phaeocystis and diatom growth.

In summary, it appears that the mechanisms of ice retreat within the Ross Sea (melting in the western Ross Sea and ice breakup and wind stress in the south central Ross Sea) control the water column structure, its stability characteristics and its iron contents. Large-scale melting, like in the western Ross
Sea, induces a highly stratified water column and allows the development of an intense diatom bloom associated with the iron-enriched coastal ice-edge region. On the contrary, in the south central Ross Sea, the processes of polynya formation result in relatively deep mixing and weakly stratified waters. Phaeocystis, as opposed to diatoms, appear to be better adapted to a less stable water column and bloom very early in spring in the polynya and the associated marginal ice zone. In addition, within the slightly stratified area of the marginal ice zone, at the northern limit of the polynya, a moderate diatom bloom overlaps with Phaeocystis. These typical patterns of phytoplankton distribution within the Ross Sea illustrate the importance of hydrodynamic processes of vertical stabilization which determine largely the dominance of diatom or Phaeocystis assemblages in Antarctic shelf waters.

\section{Acknowledgements}

This work is a part of the Belgian Research Program in the Antarctic founded by the Prime Minister's Services, Science Policy Office (SSTC Project Antar A4/DD/B21, Brussels, Belgium) in collaboration with the PNRA (Programma Nazionale 
di Ricerca in Antartide, Italy). J.H. Hecq is Research Associate from FNRS (National Foundation for Scientific Research, Belgium). Peter Sedwick and one anonymous referee are thanked for their thorough and helpful comments on the manuscript.

\section{References}

Ainley, D.G., Jacobs, S.S., 1981. Sea-bird affinities for ocean and ice boundaries in the Antarctic. Deep-Sea Res. 28, 1173-1185.

ALPKEM, 1992a. Nitrate plus nitrite in seawater. In: Alpkem (Ed.), The Flow Solution Methodology Doc. No. 000630, 8/92 Rev. B. Wilsonville, OR, USA, pp 19.

ALPKEM, 1992b. Silica in seawater. In: Alpkem (Ed.), The Flow Solution Methodology Doc. No. 000671, 5/92 Rev. A. Wilsonville, OR, USA, pp 16.

Andreoli, C., Scarabel, L.R., Tolomio, C., 1993. Distribution du picoplancton photoautotrophe dans la Baie de Terra Nova (Mer de Ross, Antarctique) pendant l'été austral 1989-1990. Algol. Stud. 68, 123-132.

Andreoli, C., Tolomio, C., Moro, I., Radice, M., Moschin, E., Bellato, S., 1995. Diatoms and dinoflagellates in Terra Nova Bay (Ross Sea - Antarctica) during austral summer 1990. Polar Biol. 15, 465-475.

Arrigo, K.R., McClain, C.R., 1994. Spring phytoplankton production in the western Ross Sea. Science 266, 261-263.

Arrigo, K.R., Robinson, D.H., Worthen, D.L., Dunbar, R.B., DiTullio, G.R., VanWoert, M., Lizotte, M.P., 1999. Phytoplankton community structure and the drawdown of nutrients and $\mathrm{CO}_{2}$ in the Southern Ocean. Science 283, 365-367.

Arrigo, K.R., Weiss, A.M., Smith, W.O.J., 1998. Physical forcing of phytoplankton dynamics in the southwestern Ross Sea. J. Geophys. Res. 103, 1007-1021.

Artegiani, A., Azzolini, R., Paschini, E., Creazzo, S., 1992. Physical oceanographic conditions in the Southern Pacific Ocean and in the Western Ross Sea. In: Anonymous, National Scientific Commission for Antarctica, Oceanographic Campaign 1989-1990. Data Report Part II, 5-62.

Barlow, R.G., Mantoura, R.F.C., Cummings, D.G., 1998. Phytoplankton pigment distributions and associated fluxes in the Bellingshausen Sea during the austral spring 1992. J. Mar. Syst. 17, 97-113.

Catalano, G., Povero, P., Fabiano, M., Benedetti, F., Goffart, A., 1997. Nutrient utilisation and particulate organic matter changes during summer in the upper mixed layer (Ross Sea, Antarctica). Deep-Sea Res. 44, 97-112.

Claustre, H., Kerhervé, P., Marty, J.C., Prieur, L., Videau, C., Hecq, J.H., 1994. Phytoplankton dynamics associated with a geostrophic front: ecological and biogeochemical implications. J. Mar. Res. 52, 711-742.

Comiso, J.C., McClain, C.R., Sullivan, C.W., Ryan, J.P., Leonard, C.L., 1993. Coastal zone color scanner pigment concentrations in the southern ocean and relationships to geophysical surface features. J. Geophys. Res. 98, 2419-2451.
DiTullio, G.R., Smith, W.O., 1995. Relationship between dimethylsulfide and phytoplankton pigment concentrations in the Ross Sea, Antarctica. Deep-Sea Res. 42, 873-892.

DiTullio, G.R., Smith, W.O.J., 1996. Spatial patterns in phytoplankton biomass and pigment distributions in the Ross Sea. J. Geophys. Res. 101, 18467-18477.

El-Sayed, S.Z., 1970. On the productivity of the Southern Ocean (Atlantic and Pacific sectors). In: Holdgate, M.W. (Ed.), Antarctic Ecology. Academic, New York, pp. 119-135.

El-Sayed, S.Z., Biggs, D.C., Holm-Hansen, O., 1983. Phytoplankton standing crop, primary productivity, and near-surface nitrogeneous nutrient fields in the Ross Sea, Antarctica. DeepSea Res. 30, 871-886.

Fryxell, G.A., Kendrick, G.A., 1988. Austral spring microalgae across the Weddell Sea ice edge: spatial relationships found along a northward transect during AMERIEZ 83. Deep-Sea Res. 35, 1-20.

Gieskes, W.W.C., Elbrächter, M., 1986. Abundance of nanoplankton-size chlorophyll-containing particles caused by diatom disruption in surface waters of the Southern Ocean (Antarctic Peninsula region). Neth. J. Sea Res. 20, 291-303.

Gieskes, W.W.C., Kraay, G.W., 1986. Analysis of phytoplankton by HPLC before, during and after mass occurrence of the microflagellate Corymbellus aureus during the spring bloom in the open northern North Sea in 1983. Mar. Biol. 92, 45-52.

Gordon, L.I., 1994. Patterns of nutrient distributions in the Ross Sea during austral summer, 1990 and 1992. EOS Trans. AGU Ocean Sci. Meet. Suppl. 75, 138.

Guillard, R.R.L., Kilham, P., 1977. The ecology of marine planktonic diatoms. In: Werner, D. (Ed.), The Biology of Diatoms. Botanical Monographs, vol. 13, Blackwell, Oxford, pp. 372 469.

Hansen, H.P., Grasshoff, K., 1983. Automated chemical analysis. In: Grasshoff, K., Ehrhardt, M., Kremling, K. (Eds.), Methods of Seawater Analysis. 2nd edn. Verlag Chemie, Weinheim, pp. 347-379.

Hecq, J.H., Magazzù, G., Goffart, A., Catalano, G., Vanucci, S., Guglielmo, L., 1992. Distribution of planktonic components related to vertical structure of water masses in the Ross Sea and the Pacific sector of the Southern Ocean. In: Anonymous, Atti del $9^{\circ}$ congresso A.I.O.L., Santa Margherita Ligure, 20-23 Novembre 1990, 665-678.

Hecq, J.H., Guglielmo, L., Goffart, A., Catalano, G., Goosse, H., 1999. Modelling approach of the ross sea plankton ecosystem. In: Faranda, F., Guglielmo, L., Ianora, A. (Eds.), Ross Sea Ecology. Italian Antarctic Expeditions (1986-1995). Springer, Berlin, pp. 395-412.

Heywood, R.B., Priddle, J., 1987. Retention of phytoplankton by an eddy. Cont. Shelf Res. 7, 937-955.

Innamorati, M., Mori, G., Lazzara, L., Nuccio, C., Lici, M., Catalano, G., Benedetti, F., 1990. Phytoplankton ecology in the Ross Sea. In: Anonymous, National Scientific Commission for Antarctica. Oceanographic Campaign 1987-1988. Data Report Part II, 9-63.

Jacques, G., Panouse, M., 1991. Biomass and composition of size fractionated phytoplankton in the Weddell-Scotia Confluence area. Polar Biol. 11, 315-328. 
Jeffrey, S.W., 1974. Profiles of photosynthetic pigments in the ocean using thin-layer chromatography. Mar. Biol. 26, 101110.

Jeffrey, S.W., 1980. Algal pigment systems. In: Falkowski, P. (Ed.), Primary Productivity in the Sea. Plenum, New York, pp. 35-58.

Jeffrey, S.W., Mantoura, R.F.C., Wright, S.W. (Eds.), 1997. Phytoplankton Pigments in Oceanography. Monographs on Oceanographic Methodology, vol. 10, Unesco Publishing, Paris,, 661 pp.

Jochem, F.J., Mathot, S., Quéguiner, B., 1995. Size-fractionated primary production in the open Southern Ocean in austral spring. Polar Biol. 15, 381-392.

Kellogg, T.B., Truesdale, R.S., 1979. Late quaternary paleoecology and paleoclimatology of the Ross Sea: the diatom record. Mar. Micropaleontol. 4, 137-158.

Knox, G.A., 1990. Primary production and consumption in Mc Murdo Sound, Antarctica. In: Kerry, K.R., Hempel, G. (Eds.), Antarctic Ecosystems, Ecological Changes and Conservation. Springer-Verlag, Berlin, pp. 115-128.

Knox, G.A., 1994. The Biology of the Southern Ocean. Cambridge Univ. Press, 444 pp.

Leventer, A., Dunbar, R.B., 1996. Factors influencing the distribution of diatoms and other algae in the Ross Sea. J. Geophys. Res. 101, 18489-18500.

Mantoura, R.F.C., Llewellyn, C.A., 1983. The rapid determination of algal chlorophyll and carotenoid pigments and their breakdown products in natural waters by reverse-phase high performance liquid chromatography. Anal. Chem. Acta 151, 297314.

Marino, D., Cabrini, M., 1997. Distribution and succession of phytoplankton populations in the Ross Sea (Antarctica) during the austral spring 1994. In: Faranda, F., Guglielmo, L., Povero, P. (Eds.), National Programme for Antarctic Research. Rossmize 1993-1995. Data Report Part I, 307-341.

Martin, J.H., Gordon, R.M., Fitzwater, S.E., 1990. Iron in Antarctic waters. Nature $345,156-158$.

Mitchell, B.G., Holm-Hansen, O., 1991. Observation and modelling of the Antarctic phytoplankton crop in relation to mixing depth. Deep-Sea Res. 38, 981-1007.

Nelson, D.M., Smith, W.O.J., 1986. Phytoplankton bloom dynamics of the western Ross Sea ice edge: II. Mesoscale cycling of nitrogen and silicon. Deep-Sea Res. 33, 1389-1412.

Nelson, D.M., Ahern, J.A., Herlihy, L.J., 1991. Cycling of biogenic silica within the upper water column of the Ross Sea. Mar. Chem. 35, 461-476.

Nelson, D.M., Tréguer, P., 1992. Role of silicon as a limiting nutrient to Antarctic diatoms: evidence from kinetic studies in the Ross Sea ice-edge zone. Mar. Ecol. Prog. Ser. 80, 255-264.

Nelson, D.M., DeMaster, D.J., Dunbar, R.B., Smith, W.O.J., 1995. Cycling of organic carbon and biogenic silica in the Southern Ocean: large-scale estimates of water-column and sedimentary fluxes in the Ross Sea. Carbon fluxes and dynamic processes in the Southern Ocean: Present and Past, Brest (France), 28-31 August 1995, International Symposium, Programme. pp. 132-133.

Palmisano, A.C., SooHoo, J.B., SooHoo, S.L., Kottmeier, S.T., Craft, L.L., Sullivan, C.W., 1986. Photoadaptation in Phaeocystis pouchetii advected beneath annual sea ice in McMurdo Sound, Antarctica. J. Plankton Res. 5, 891-906.

Russo, A., Gallarato, A., Testa, G., Corbo, C., Pariante, R., 1997. Physical data collected during ROSSMIZE cruise (Ross Sea, November-December 1994). In: Faranda, F., Guglielmo, L., Povero, P. (Eds.), National Programme for Antarctic Research. Rossmize 1993-1995. Data Report Part I, 25-110.

Sedwick, P.N., DiTullio, G.R., 1997. Regulation of algal blooms in Antarctic shelf waters by the release of iron from melting sea ice. Geophys. Res. Lett. 24, 2515-2518.

Sedwick, P.N., DiTullio, G.R., Mackey, D.J., 2000. Iron and manganese in the Ross Sea, Antarctica: seasonal iron limitation in Antarctic shelf waters. J. Geophys. Res. 105, 1132111336.

Smith, W.O.J., Nelson, D.M., 1985. Phytoplankton bloom produced by a receding ice edge in the Ross Sea: spatial coherence with the density field. Science $227,163-166$.

Smith, W.O., Nelson, D.M., 1986. Importance of ice edge phytoplankton production in the Southern Ocean. Bioscience 36, 251-257.

Smith, W.O.J., Gordon, L.I., 1997. Hyperproductivity of the Ross Sea (Antarctica) during austral spring. Geophys. Res. Lett. 24, 233-236.

Smith, W.O., Nelson, D.M., DiTullio, G.R., Leventer, A.R., 1996. Temporal and spatial patterns in the Ross Sea: phytoplankton biomass, elemental composition, productivity and growth rates. J. Geophys. Res. 101, 18455-18465.

Tréguer, P., Gordon, L.I., Nelson, D.M., 1994. N/Si/P uptake ratios in the surface layer of the ross sea during summer, 1990 and 1992. EOS Trans. AGU Ocean Sci. Meet. Suppl. 75, 138-139.

Vernet, M., Lorenzen, C.J., 1987. The relative abundance of pheophorbide $a$ and pheophytin $a$ in temperate marine waters. Limnol. Oceanogr. 32, 352-358.

Welschmeyer, N.A., Lorenzen, C.J., 1985. Chlorophyll budgets: zooplankton grazing and phytoplankton growth in a temperate fjord and the Central Pacific Gyres. Limnol. Oceanogr. 30, $1-21$.

Williams, R., Claustre, H., 1991. Photosynthetic pigments as biomarkers of phytoplankton populations and processes involved in the transformation of particulate organic matter at the Biotrans site $\left(47^{\circ} \mathrm{N}, 20^{\circ} \mathrm{W}\right)$. Deep-Sea Res. 38, 347-355.

Wilson, D.L., Smith, W.O., Nelson, D.M., 1986. Phytoplankton bloom dynamics of the Western Ross Sea ice-edge: 1. Primary productivity and species-specific production. Deep-Sea Res. 33, 1375-1387. 